\title{
Hirsutanol A, a novel sesquiterpene compound from fungus Chondrostereum sp., induces apoptosis and inhibits tumor growth through mitochondrial-independent ROS production: Hirsutanol A inhibits tumor growth through ROS production
}

Fen Yang ${ }^{1+}$, Wen-Dan Chen ${ }^{1+}$, Rong Deng ${ }^{1}$, Hui Zhang ${ }^{3}$, Jun Tang ${ }^{1}$, Ke-Wei Wu' ${ }^{1}$ Dan-Dan Li ${ }^{1}$, Gong-Kan Feng ${ }^{1}$, Wen-Jian Lan ${ }^{4}$, Hou-Jin Li ${ }^{2^{*}}$ and Xiao-Feng Zhu ${ }^{1 *}$

\begin{abstract}
Background: Hirsutanol A is a novel sesquiterpene compound purified from fungus Chondrostereum sp. in Sarcophyton tortuosum. Our previous studies had demonstrated that hirsutanol A exhibited potent cytotoxic effect on many kinds of cancer cell lines. In the current study, the antitumor activity of hirsutanol A and its molecular mechanisms were investigated.

Methods: Hirsutanol A induced growth inhibition and apoptotic cell death of human colon cancer SW620 cells and human breast cancer MDA-MB-231cells were determined using MTT assay and flow cytometry assay, respectively. The effect of hirsutanol A on intrinsic ROS level and change in mitochondrial membrane potential $(\Delta \psi \mathrm{m})$ of different cell lines were also measured by flow cytometry assay. The function of JNK was compromised by JNK siRNA or JNK inhibitor SP600125. The expression of cytochrome c, p-JNK, p-c-Jun after treatment with hirsutanol A were detected by Western blot analysis. Finally, the in vivo anti-tumor effect of hirsutanol A was examined in human cancer cell SW620 xenograft model.

Results: The results showed that hirsutanol A significantly induced apoptosis, mitochondrial-independent increase of Reactive Oxygen Species (ROS) level, change of mitochondrial membrane potential, release of cytochrome $c$ in human cancer cells. Preventing increase of ROS level using the potent antioxidant N-acetyl-L-cysteine (NAC) markedly decreased hirsutanol A-induced apoptosis. In addition, JNK signaling pathway was activated by hirsutanol A through elevating ROS level. Blockade of JNK signaling pathway by JNK specific inhibitor SP600125 enhanced apoptosis and hirsutanol A-induced ROS accumulation. Also, hirsutanol A exhibited antitumor activity in human cancer cell SW620 xenograft model.
\end{abstract}

Conclusion: These data suggested that hirsutanol A inhibited tumor growth through triggering ROS production and apoptosis.

Keywords: Hirsutanol A, Apoptosis, JNK, Mitochondria, ROS, Cancer

\footnotetext{
* Correspondence: ceslhj@mail.sysu.edu.cn; zhuxfeng@mail.sysu.edu.cn

${ }^{\dagger}$ Equal contributors

${ }^{2}$ School of Chemistry and Chemical Engineering, Sun Yat-Sen University,

Guangzhou 510275, China

'State Key Laboratory of Oncology in South China, Cancer Center, Sun Yat-

Sen University, 651 Dongfeng Road East, Guangzhou 510060, China

Full list of author information is available at the end of the article
} 


\section{Background}

ROS (Reactive Oxygen Species) is a collective term for oxygen derived species, including superoxide anion radical $\mathrm{O}_{2}^{-}$, hydroxyl radicals $\mathrm{OH}$ etc. [1]. The basic level of intracellular ROS is considered to be important to promote cell proliferation and differentiation. However, excessive amounts of ROS can contribute to carcinogenesis and cancer progression [2,3]. Therefore, maintaining ROS homeostasis is crucial for normal cell growth and survival [4]. Compared to normal cells, cancer cells with increasing intrinsic ROS are more vulnerable to damage by further ROS insults induced by exogenous agents [5]. Manipulating ROS levels by redox modulation is one way to selectively kill cancer cells sparing normal cells. Hence, the redox system is considered as a new target for anticancer drugs [6,7].

Apoptosis is a highly regulated and organized cell death process, which controls the development and homeostasis of multicellular organisms [8]. Death receptor signaling pathway and mitochondrial pathway are two major pathways mediating apoptosis triggered by different apoptotic stimuli $[9,10]$. Alterations in the cellular ROS status have been proven to play an important role in apoptotic cell death [11]. Excessive ROS will attack lipids and proteins of mitochondria membrance, leading to severe and irreversible oxidative damage, dysfunction of mitochondria, and release of cytochrome $c$, which in turn activates the caspase-3 initiating mitochondria / cytochrome $c$-mediated apoptosis [12,13].

C-Jun NH2-terminal kinases (JNKs) are strongly activated by oxidative stress, which can induce apoptosis or regulate cellular ROS level by activating its downstream molecule cJun [14]. C-Jun is fisrt phosphorylated by JNK and then translocates to the nucleus for further regulating the transcription of target genes including some pro-apoptotic or antiapoptotic proteins such as Bax and $\mathrm{Bcl}-2$ and some redox proteins such as NOX, SOD $[15,16]$.

Hirsutanol A is a novel sesquiterpene compound purified from fungus Chondrostereum sp. in Sarcophyton tortuosum [17]. Our previous studies showed that Hirsutanol A exerted potent cytotoxic effect on many kinds of human cancer cell lines $[18,19]$. In this study, we examined the molecular mechanism of Hirsutanol A-induced apoptosis and its antitumor activity in human cancer cell SW620 xenograft model. We demonstrated that Hirsutanol A could induce apoptosis in SW620 and MDA-MB-231 cells and significantly inhibit tumor growth in vivo. Futhermore, we found that hirsutanol A could elevate intrinsic ROS level, and activate mitochondria/ cytochrome $c$ signaliing pathway to trigger apoptosis.

\section{Methods}

\section{Drugs and reagents}

Fetal bovine serum and RPMI-1640 media were purchased from Gibco $^{\circledR}$ (New York, USA). 3-(4,5-dime- thylthiazol-2- thiazolyl)-2,5-diphenyltetrazolium bromide (MTT), CM-H2DCF-DA, Dimethyl sulfoxide (DMSO), $\mathrm{N}$-acetyl-L-cysteine (NAC) were obtained from SigmaAldrich (St. Louis, USA). 10-Hydroxycamplothecin (HCPT) was purchased from Huangshi Feiyun Pharmaceutical Co., Ltd (Hubei, China). Antibodies against Hsp60, JNK, p-JNK, chemiluminescence reagent were acquired from Cell Signaling Technology (Danvers, MA, USA). Antibodies against GAPDH, Caspase-3, PARP, Cyto-c, p-c-Jun and anti-mouse Ig-G-horseradish peroxidase, anti-rabbit Ig-G-horseradish peroxidase were from Santa Cruz Biotechnology (Santa Cruz, USA). The c-Jun antibody was purchased from Boster Biotech (Wuhan, Hubei, China). Cell lysis was from Upstate Biotech Co (New York, USA). Hirsutanol A, a sesquiterpene compound, was isolated from fungus Chondrostereum sp. in Sarcophyton tortuosum, and initially dissolved in $100 \%$ DMSO at $100 \mathrm{nM}$ and stored at $-20^{\circ} \mathrm{C}$. Its structure is shown in Figure 1.

\section{Cell lines and cell culture}

Human colon cancer cell line SW620 and human breast cancer cell line MDA-MB-231 were cultured in RPMI1640 media supplemented with $10 \%$ heat-inactivated fetal bovine serum, penicillin $(50 \mathrm{U} / \mathrm{ml})$ and streptomycin $(50 \mu \mathrm{g} / \mathrm{ml})$ at $37^{\circ} \mathrm{C}$ in $5 \%(\mathrm{v} / \mathrm{v}) \mathrm{CO}_{2}$. All experiments were carried out with cells in logarithmic growth phase.

\section{MTT assay}

SW620 and MDA-MB-231 cells were first seeded in 96well plate at a density of 8,000 cells per well, then treated with different concentrations of hirsutanol A for indicated times or pre-incubated with $1 \mathrm{mmol} / \mathrm{L}$ antioxidant NAC for $1 \mathrm{~h}$, then cultivated for $72 \mathrm{~h}$ at $37^{\circ} \mathrm{C}$. $10 \mu \mathrm{L}$ of $5 \mathrm{mg} / \mathrm{mL}$ MTT was added into each well before the termination of experiment. The plates were incubated at $37^{\circ} \mathrm{C}, 5 \%(\mathrm{v} / \mathrm{v}) \mathrm{CO}_{2}$ for $4 \mathrm{~h}$. After complete removal of the medium, $100 \mu \mathrm{L}$ of DMSO was added into each well to dissolve the insoluble purple formazan product. Absorbance values were obtained with a test wavelength of $570 \mathrm{~nm}$. The rates of cell growth inhibition were calculated based on the absorbance values.

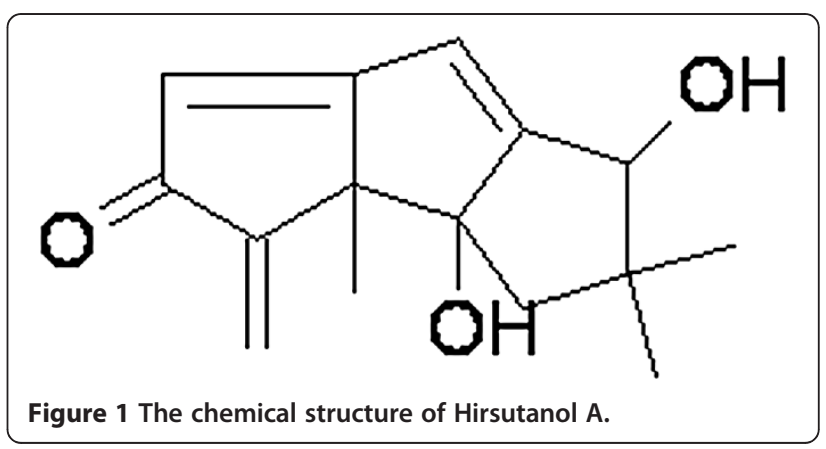


The $50 \%$ inhibitory rates (\%) were calculated by the Bliss method: Inhibitory rate $=(1$-the average $\mathrm{OD}$ value of treatment group/ the average OD value of the control group) $\times 100 \%[20]$.

\section{Annexin V/Propidium Idodide (PI) double-staining assay} Annexin V/PI staining was performed using the Annexin V-fluorescein isothiocyanate apoptosis detection kit. Cells $\left(3.0 \times 10^{5}\right.$ per $\left.\mathrm{mL}\right)$ were seeded into six-well plate with $2 \mathrm{~mL}$ in each well, then treated with different concentrations of hirsutanol A for $72 \mathrm{~h}$ or pretreated with $1 \mathrm{mmol} / \mathrm{L} \mathrm{NAC} \mathrm{or} 10 \mu \mathrm{mol} / \mathrm{L}$ SP600125 followed by hirsutanol A for $72 \mathrm{~h}$. Both floating and attached cells were collected, washed with ice-cold PBS twice, then incubated at room temperature in the presence of media binding reagent and Annexin V-FITC for $15 \mathrm{~min}$ in the dark. After washing with PBS, the cells were resuspended in ice-cold $1 \times$ binding buffer and treated with $10 \mu \mathrm{L}$ propidium iodide $(30 \mu \mathrm{g} / \mathrm{ml})$ on ice in the dark. Apoptosis was quantified by flow cytometry (Becton Dickinson) at the wavelength of $488 \mathrm{~nm}$ immediately and analyzed by the Cell-Quest software [21].

\section{Flow cytometry assay and measurement of ROS}

Cells were diluted to $3.0 \times 10^{5}$ per $\mathrm{mL}$, seeded into six-well plate with $2 \mathrm{~mL}$ in each well. SW620 cells and MDA-MB231 cells were treated with hirsutanol A for indicated times or treated with various concentrations of hirsutanol A for $24 \mathrm{~h}$, or pre-incubated with $1 \mathrm{mmol} / \mathrm{L} \mathrm{NAC} \mathrm{or} 1 \mu \mathrm{mol} / \mathrm{L}$ SP600125 followed by hirsutanol A for $24 \mathrm{~h}$, then incubated with $1 \mu \mathrm{mol} / \mathrm{L}$ (final concentration) CM-H2DCF-DA or DHE florescent dye in dark for $1 \mathrm{~h}$ at $37^{\circ} \mathrm{C}$. After washing twice with ice cold PBS, cells were centrifuged and resuspended in PBS. The level of intracellular ROS was detected by flow cytometry with FACS Calibur system and CellQuestPro analysis software [22].

\section{Immunoblotting analysis}

Cells were seeded into six-well plate, treated with hirsutanol A for indicated times or pre-incubated with NAC for $1 \mathrm{~h}$ followed by hirsutanol A for $24 \mathrm{~h}$. Cells were harvested and washed twice with PBS and lysed in lysis buffer. The cell lysates were clarified by centrifugation at $12,000 \mathrm{~g}$ for $10 \mathrm{~min}$ at $4^{\circ} \mathrm{C}$ and the protein concentration was determined using the Bio-Rad protein assay (BioRad laboratories). SDS-PAGE sample buffer was added to cell lysates. Then the cell lysates were heated at $100^{\circ} \mathrm{C}$ for $5 \mathrm{~min}$, and cell lysates containing 20-40 $\mu \mathrm{g}$ protein was loaded in each well of $8 \%(w / v)$ and $15 \%(w / v)$ SDSPAGE gel. Resolved proteins were electrophoretically transferred to PVDF membrane, which was incubated sequentially with primary antibody and horseradish peroxidase-conjugated second antibody. After washing, the bound antibody complex was detected using an ECL chemiluminescence reagent and XAR film (Kodak) as described by the manufactures $[23,24]$.

\section{siRNA transfection}

The target sequence for JNK-specific siRNA was $5^{\prime}$ AAAAAGAAUGUCCUAC CUUCU-3', and control siRNA (no silencing) were synthesized by GenChem Co. One day before transfection, cells were plated in six-well plates with antibiotic-free growth medium at a density of $1.5 \times 10^{5}$ cells per well. When cells grew to a confluency of $30-50 \%$ on the second day, transfection was performed by using Opti-MEM media, lipofectamine 2000 and JNK siRNA according to manufacturer's recommendations. The final concentration of JNK siRNA was 100 nM. After $6 \mathrm{~h}$, the Opti-MEM media was replaced with the antibiotic free growth media and cells were treated with $20 \mu \mathrm{mol} / \mathrm{L}$ hirsutanol A for $3 \mathrm{~h}$.Cells transfected with lipofectamine 2000 were used as control [25].

\section{Mitochondrial /cytosol fractionation}

The isolation of cell mitochondrial and cytosolic fractions was performed using mitochondria/cytosol fractionation kit according to the following protocol. Cells previously treated with $20 \mu \mathrm{mol} / \mathrm{L}$ hirsutanol A for $24 \mathrm{~h}$ were harvested at $\sim 850 \times \mathrm{g}$ for $2 \mathrm{~min}$ and $800 \mu \mathrm{l}$ of mitochondria isolation reagent $\mathrm{A}$ and $10 \mu \mathrm{l}$ of mitochondria isolation reagent $B$ were added. After 5 min incubation on ice, $800 \mu$ l of mitochondria isolation reagent $\mathrm{C}$ was added and the mixture was centrifuged at $700 \times \mathrm{g}$ for 10 $\min$ at $4^{\circ} \mathrm{C}$. The supernatant was further centrifuged at $12,000 \times \mathrm{g}$ for $15 \mathrm{~min}$ at $4^{\circ} \mathrm{C}$ in order to pellet the crude mitochondria. $500 \mu \mathrm{l}$ mitochondria isolation reagent $\mathrm{C}$ was then added to the pellet before the final centrifugation at $12,000 \times \mathrm{g}$ for $5 \mathrm{~min}$ at $4^{\circ} \mathrm{C}$. The resulting mitochondrial pellet and cytosol fraction were lysed by lysis buffer before further processing [26].

\section{In vivo antitumor studies}

BALB/c nude mice (4 to 6 week-old) were obtained from Guangzhou University of Chinese Medicine. All manipulation was done under sterile conditions. The procedures involving mice and their care were in accordance with National Institutes of Health Guide for the care and use of Laboratory Animals and with the United Kingdom Coordinating Committee on Cancer Research. Tumor xenografts were established by injecting $1 \times 10^{6}$ SW620 cells into the subcutaneous tissue in both flank of nude mice. Mice were randomly divided into six groups and each group contained 6 mice. Treatment was initiated on day 6 after inoculation, by which time the volume of the tumor had reached approximately $50 \mathrm{~mm}^{3}$. Different concentration of hirsutanol A $(20 \mathrm{mg} / \mathrm{kg} / \mathrm{d}, 10 \mathrm{mg} / \mathrm{kg} / \mathrm{d}$, $5 \mathrm{mg} / \mathrm{kg} / \mathrm{d}$ ), DMSO, 0.9\% (w/v) $\mathrm{NaCl}$ Saline (N.S.) and 
HCPT were administered i.p. for 28 days for the assigned group. Tumor volumes and body weight of the mice were observed. Tumor volumes were calculated by the formula: $0.5 \times \mathrm{a} \times \mathrm{b}^{2}$ in millimeters, where $\mathrm{a}$ is the length and $b$ is the width. On day 28 after administration, the mice were sacrificed. The tumor tissues were excised and weighed. Tumor growth inhibition was determined as the ratio of the average tumor weight of the treated group ( $\mathrm{T}$ ) to the average tumor weight of the control group (C) [27].

\section{Statistical analysis}

Data were analyzed by student's t test with SPSS 11.0 analysis software, and results were considered statistically significant at $\mathrm{p}<0.05$. Results are presents as mean and standard deviation $( \pm \mathrm{SD})$.

\section{Results}

Hirsutanol A inhibited proliferation and induced apoptosis in SW620 and MDA-MB-231 cells

Using MTT assay, we found that hirsutanol A inhibited cell proliferation in a dose- and time- dependent manner. The half-maximal inhibitory concentration $\left(\mathrm{IC}_{50}\right)$ were $1.90 \mu \mathrm{mol} / \mathrm{L}, 6.16 \mu \mathrm{mol} / \mathrm{L}, 13.43 \mu \mathrm{mol} / \mathrm{L}$ for SW620 cells and $10.48 \mu \mathrm{mol} / \mathrm{L}, 18.01 \mu \mathrm{mol} / \mathrm{L}, 35.67$ $\mu \mathrm{mol} / \mathrm{L}$ for MDA-MB-231 cells after treatment with hirsutanol A for 72, 48, 24 h respectively (Figure 2A). Inhibition of cell growth could be the consequences of the induction of apoptosis, necrosis and cell growth arrest [28]. Thereby, we investigated whether hirsutanol A could induce apoptosis in SW620 and MDA-MB-231 cells. Phosphatidyl serine translocation to the cell surface is an important indicator of early apoptosis [29]. AnnexinVfluorescein isothiocyanate/propidium iodide staining assay

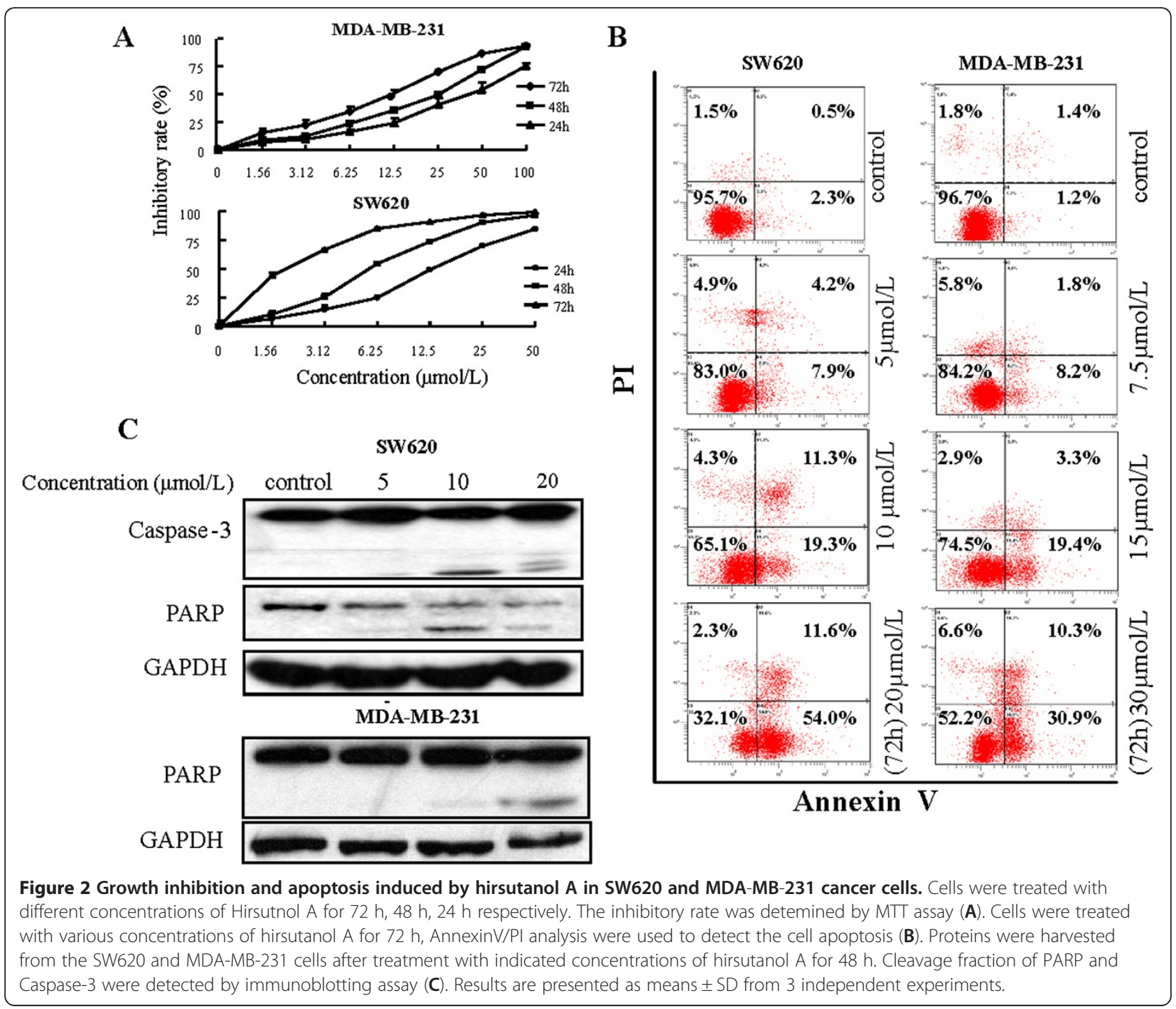


was also employed to monitor the apoptotic cells. The percentages of AnnexinV-positive cells were 2.8\%, 12.1\%, $45.0 \%, 65.6 \%$ in SW620 and 2.6\%, 10.0\%, 22.7\%, 30.6\% in MDA-MB-231 after treatment with various concentrations of hirsutanol A for $72 \mathrm{~h}$. These data indicated that hirsutanol A could induce apoptosis in a dose-dependent manner (Figure 2B). Furthermore, with Western blot analysis we found that pro-caspase-3 was cleaved to form a $17 \mathrm{KDa}$ fragment and PARP was cleaved into an $89 \mathrm{KD}$ fragment (Figure $2 \mathrm{C}$ ). These results suggest that hirsutanol A significantly induced apoptosis in SW620 and MDA-MB-231 cells.

\section{Hirsutanol A induced mitochondrial-independent accumulation of intrinsic ROS}

Previous studies had confirmed that hirsutanol A could induce autophagical cell death by causing an accumulation of ROS level in human hepatocellular carcinoma cells [18]. As reactive oxygen species mainly include hydrogen peroxide $\mathrm{H}_{2} \mathrm{O}_{2}$ and superoxide anion radical $\mathrm{O}_{2}^{-}$, in the present study, the effect of hirsutanol A on cellular superoxide and hydrogen peroxide level was measured in SW620 cells and MDA-MB-231 cells. The level of superoxide and hydrogen peroxide in cancer cells were analyzed by flow cytometry using DHE and CM-H2DCF-DA as fluorescent probe [30,31]. There was no significant change in DHE fluorescence after treatment with hirsutanol A for $3 \mathrm{~h}$ but a remarkable increase of CM-H2DCF-DA fluorescence in a dose-dependent fashion (Figure $3 \mathrm{~A}$ and $3 \mathrm{~B}$ ), suggesting that the ROS induced by hirsutanol A were mainly hydrogen peroxide instead of superoxide. Since accumulation of ROS was mainly caused by the increase of mitochondrial respiratory chain production and decrease of capability for scavenging ROS by the redox system, we thereby investigated whether hirsutanol A-induced increase of ROS was related to mitochondria. C6F cells, a clone of rho-0 cells (mitochondrial respiration defective) derived from HL-60 cells and parental HL-60, were used to detect whether hirsutanol A-induced accumulation of ROS production was mitochondrial respiratory chain related. Results showed that both the parental HL-60 and roh-0 cells (C6F) were highly sensitive to hirsutanol A. C2, C8 cells (rho-0 cells) and parental Raji cells also showed similar effect after treatment with hirsutanol A, which suggested that the accumulation of ROS production were mitochondrial respiratory chain independent (Figure 3C).

\section{Preventing ROS accumulation by antioxidant agent NAC reduced hirsutanol $\mathrm{A}$-induced apoptosis}

Excessive ROS could lead to mitochondrial membrane damage, the release of cytochrome $c$ from mitochondrial and cell apoptosis. The evidences of apoptosis and upregulation of ROS levels in cells treated with hirsutanol A prompted us to investigate whether up-regulation of ROS would resulted in apoptosis. The increase of ROS levels in hirsutanol A-treated cancer cells was prevented

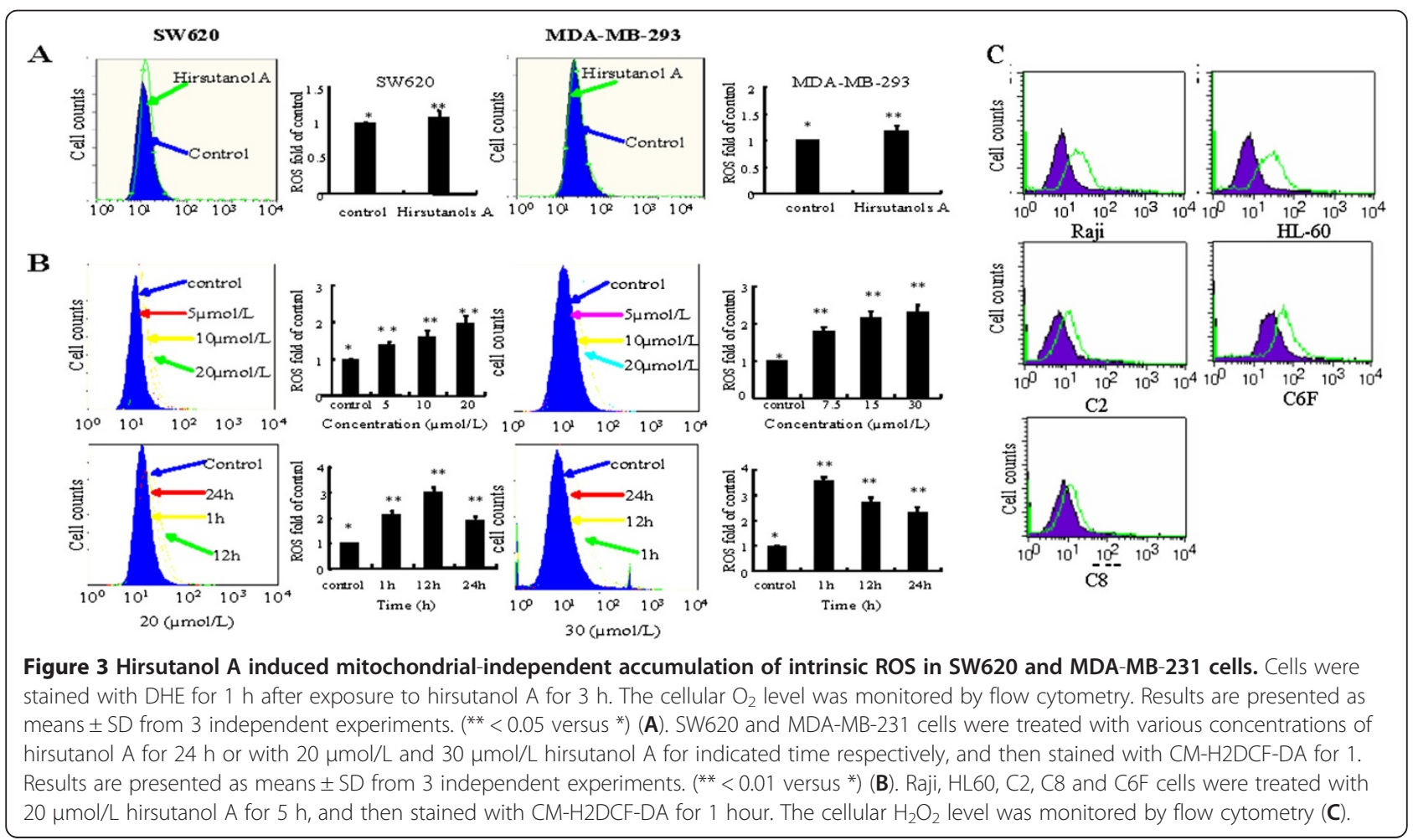


by pre-incubation with NAC for $1 \mathrm{~h}$. Cell growth inhibition was analyzed using MTT assay and AnnexinVpositive cells were detected by Annexin V/PI double staining assay (Figure $4 \mathrm{~A}$ to $4 \mathrm{C}$ ). The results showed that hirsutanol A-induced AnnexinV-positive cells and growth inhibition were significantly reduced. In addition, prevention of ROS accumulation could inhibit the PARP cleavage in hirsutanol A-treated cells (Figure 4D). These data suggested that accumulation of ROS mediated hirsutanol A-induced apoptosis.

\section{Hirsutanol A activated mitochondria/cytochrome c signaling pathway}

To further study whether hirsutanol A induced apoptosis via activation of mitochondria/cytochrome $c$ signaling pathway, we examined the change of mitochondrial membrane potential and the release of cytochrome $c$ from mitochondria. Mitochondrial membrane potential was elevated after treatment with various concentrations of hirsutanol A (Figure 5A). The expression of cytochrome $c$ in mitochondria was down-regulated, whereas cytosolic cytochrome $c$ was increased after treatment with hirsutanol A for $24 \mathrm{~h}$ (Figure 5B). These data revealed that hirsutanol $\mathrm{A}$ induced apoptosis through activation of mitochondria/cytochrome $c$ signaling pathway.

\section{Hirsutanol A activated JNK signaling pathway and} blockade of JNK signal pathway increased ROS level and cell apoptosis

It has been reported that ROS can modulate several signaling pathways including JNK, Akt, NF-kB etc. [32,33]. Therefore, we explored the effect of increased ROS by hirsutanol A on JNK signaling pathway. JNK and c-Jun phosphorylation were significantly elevated in SW620 cells after treatment with hirsutanol A for $24 \mathrm{~h}$ (Figure 6A). However, this activation of JNK could be

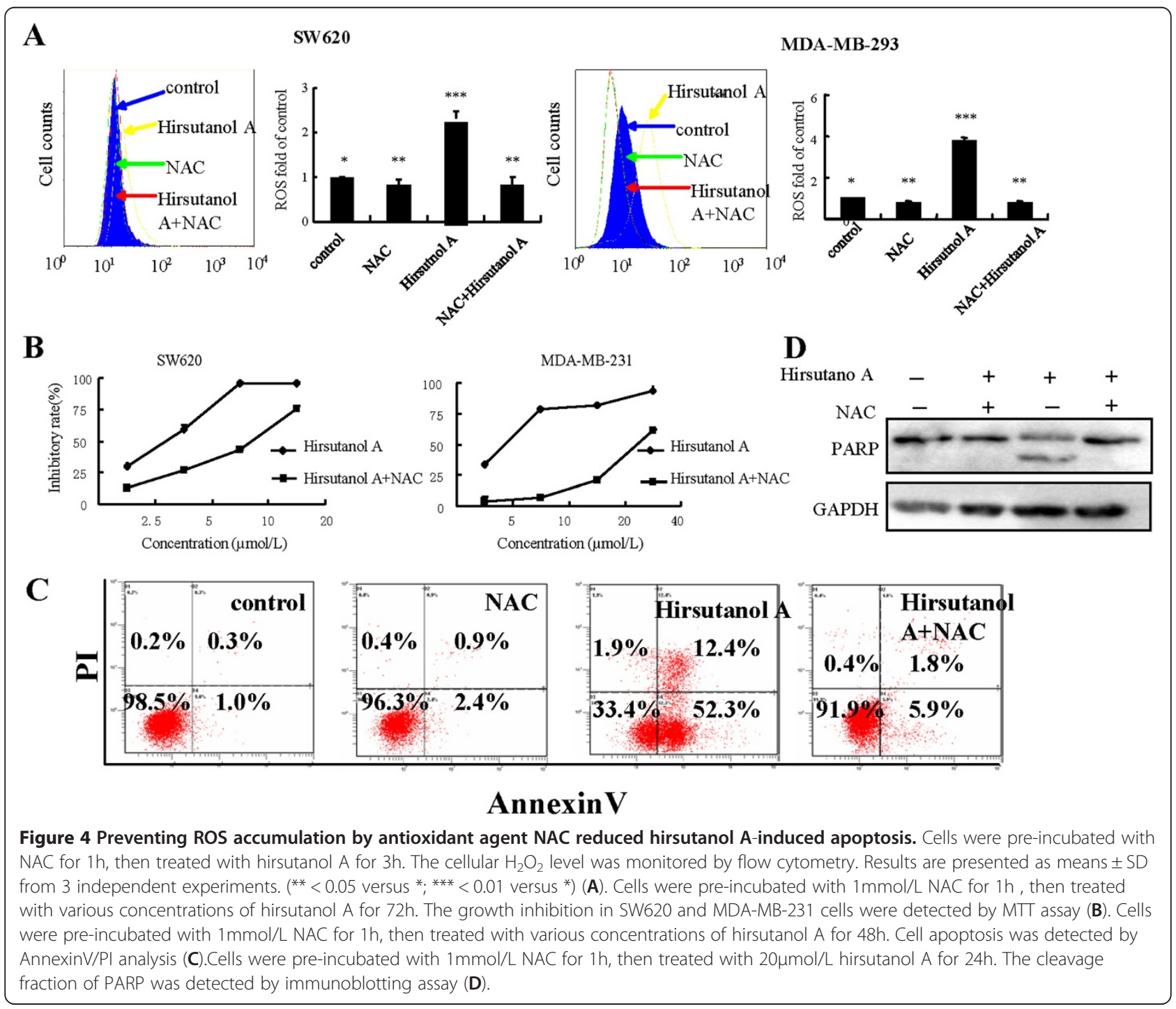




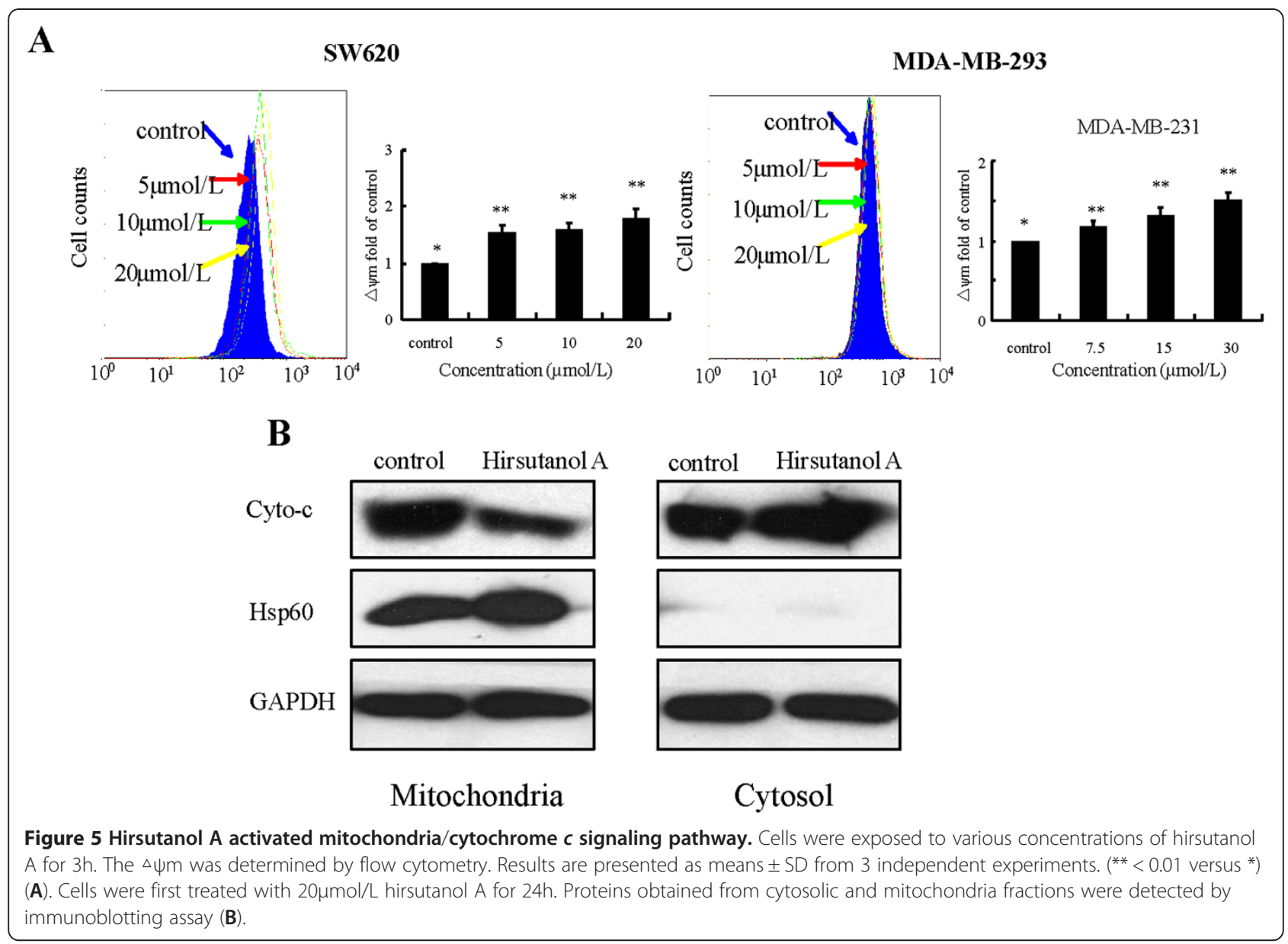

blocked by antioxidant agent NAC (Figure 6B). These suggested that JNK may be a downstream target of excessive ROS. In order to further explore the contribution of JNK signaling pathway to hirsutanol A-induced ROS accumulation, JNK signaling pathway was blocked using the small molecule JNK inhibitor SP600125 [34]. The percentage of AnnexinV- positive cells was $35.6 \%$ when cells were treated with hirsutanol A only, , whereas in parallel treatment in combination with SP600125, the percentage of AnnexinV-positive cells was $48.3 \%$, suggesting that blocking of JNK signaling pathway promoted hirsutanol A-induced apoptosis (Figure 6C). The results also revealed that inhibiting JNK signaling pathway enhanced the growth inhibition effect induced by hirsutanol A (Figure 6D).

We further investigated the effect of activation of JNK signaling pathway on cellular ROS levels. Cellular ROS levels were remarkably increased in SW620 cells by JNK inhibitor SP600125 or JNK-siRNA (Figure 6E).These results suggested that activation of JNK could be one response to oxidant stress which protects cells from death via regulation of ROS in a negative feedback manner. It was not a classic mechanism involved in apoptosis.

\section{In vivo antitumor effect of hirsutanol A on human colon cancer cell SW620 xenografts}

To detect the antitumor activity of hirsutanol A in vivo, human colon cancer SW620 xenografts were established. The results showed that hirsutanol A at $10 \mathrm{mg} / \mathrm{kg} / \mathrm{d}$ potently inhibited tumor growth (Figure 7).

\section{Discussion}

Hirsutanol A is a novel sesquiterpene compound purified from fungus Chondrostereum sp. in Sarcophyton tortuosum. Our previous studies had demonstrated that hirsutanol A exhibited potent cytotoxic effect on some human cancer cell lines. In addition, we also confirmed that hirsutanol A could induce autophagical cell death by causing accumulation of ROS level in human hepatocellular carcinoma cells [18]. ROS inducer as an anticancer drug has received a lot of attention due to its selective effect on cancer cells but sparing normal cells 


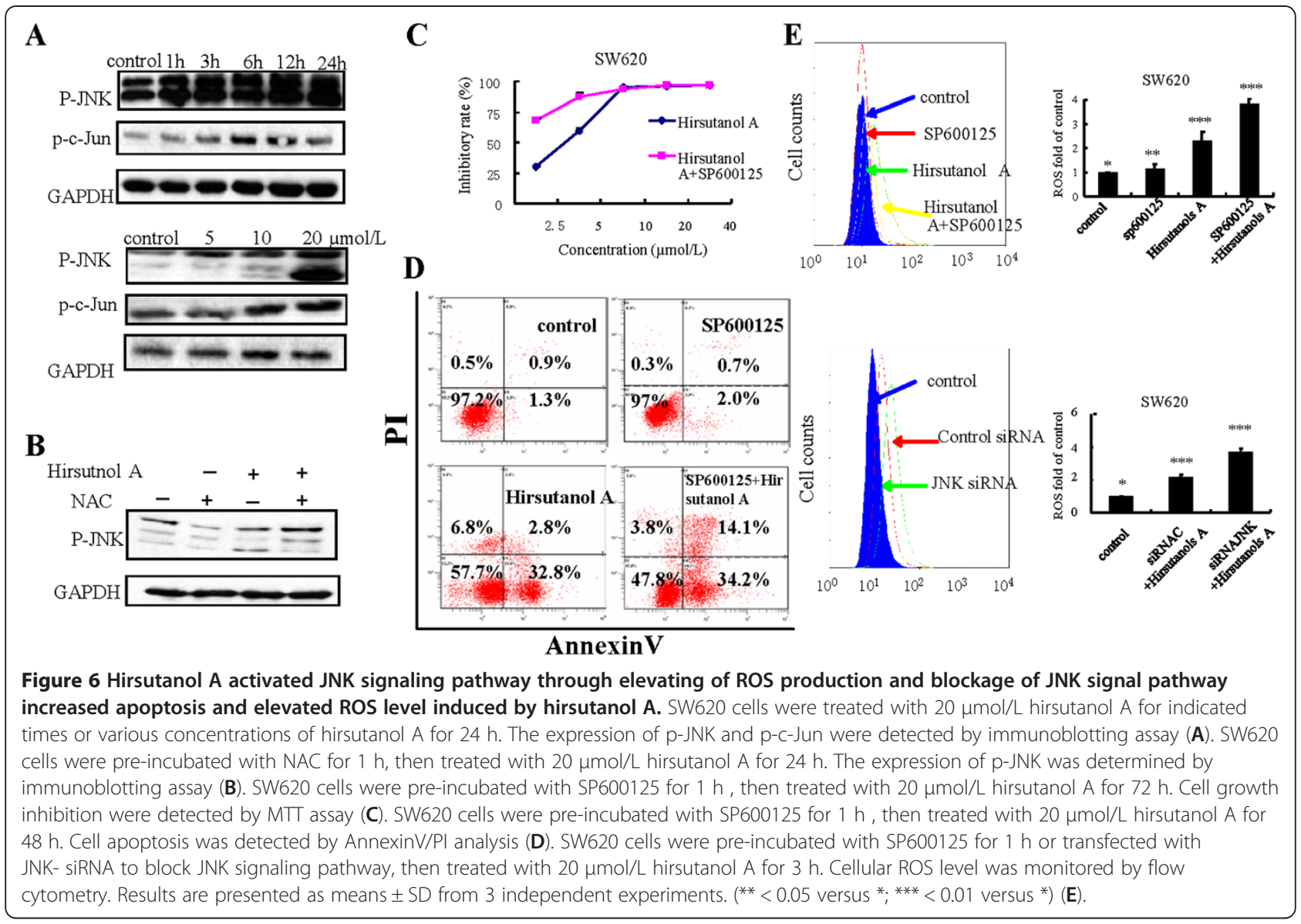

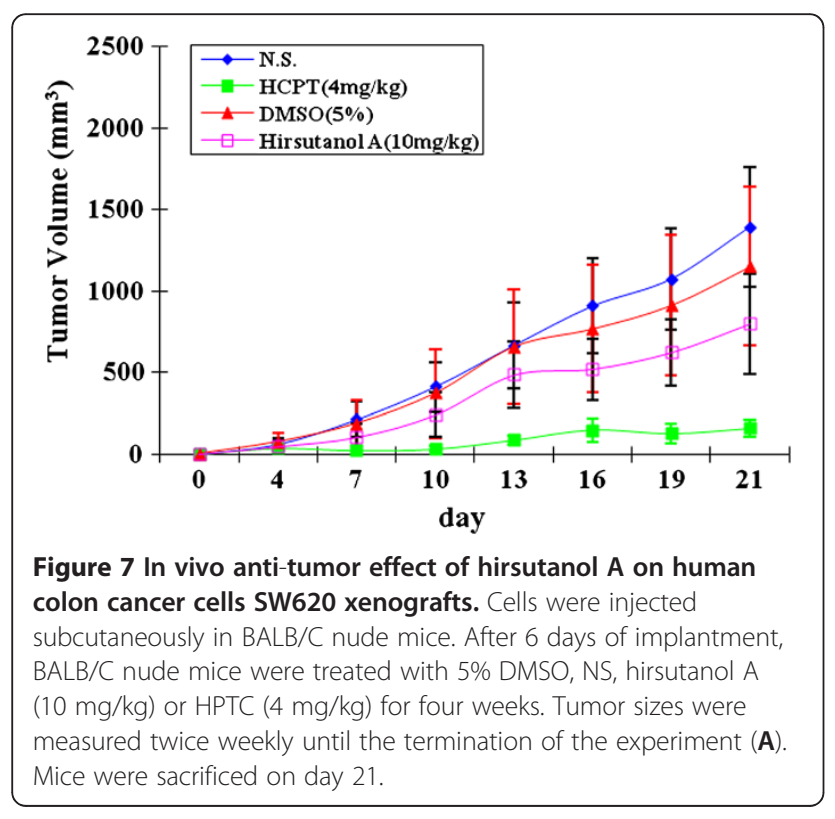

[35]. To date, there are some ROS inducers targeting ROS generating system or ROS scavenging system $[7,36]$. However, most of them cannot enter clinical trials because of the high toxicity or poor bioavailability. Here, we reported that hirsutanol A could significant induce cell growth inhibition and apoptosis, elevate the level of ROS in both SW620 and MDA-MB-231 cells and suppress tumor growth in SW620 xenografts (Figures 2, 3 and 7). Some evidences supported that ROS as a potent oxidant agent could damage mitochondrial membrane to result in mitochondrial membrane potential disorder and release of cytochrome $c$ from mitochondria which could further activate caspase-3, leading to mitochondria/cytochrome $c$-mediated apoptosis [37]. We had examined the mitochondrial membrane potential and the expression of cytochrome $c$ in mitochondria and cytosol. The results showed that hirsutanol A could trigger the dysfunction of mitochondrial membrane potential and release of cytochrome $c$ from mitochondria (Figure 5). Furthermore, we evaluated whether hirsutanol A-induced growth inhibition and apoptosis were evoked by accumulation of ROS. After treatment with NAC, a potent antioxidant agent that could prevent hirsutanol A-induced ROS accumulation [38], we found 
that cell growth inhibition and apoptosis remarkably decreased (Figure 4). As our data has clearly demonstrated that hirsutanol A could elevate intrinsic ROS level, and activate mitochondria/cytochrome $c$ signaliing pathway to trigger apoptosis, further studies are required to elucidate if the release of cytochrome $c$ is due to the elevated ROS induced by hirsutanol A.

ROS, which serves as a second messenger, can modulate several signaling pathways including JNK, Akt, NF-kB etc. $[32,33]$. In this study, we showed that hirsutanol A enhanced the phosphorylation levels of JNK and c-Jun dose-and timedependently in SW620 cells (Figure 6A). Moreover, prevention of hirsutanol A-induced ROS accumulation by NAC could reverse the phosphorylation of JNK and c-Jun (Figure 6B). These data indicated that hirsutanol A-induced production of ROS activated JNK signaling pathway. JNK signaling pathway is involved in both stress-induced and chemotherapeutical drugs-induced apoptosis. However, inhibition of JNK signaling pathway by a special inhibitor SP600125 promoted the hirsutanol A-induced cell growth inhibition and apoptosis. Mass evidences verified that JNK signaling pathway is responsible for regulation of ROS level by activating c-Jun, a transcription factor, which further regulates the transcription of some target genes involved in redox such as NOX and SOD, etc. [39,40]. In our studies, we found that blockade of JNK signaling pathway by SP600125 and siRNA-JNK could significantly enhance hirsutanol A-induced ROS production, suggesting that hirsutanol A-induced activation of JNK signaling pathway regulated ROS level in a negative feedback manner. These evidences point us in the direction that treatment with hirsutanol A in combination with inhibitor of JNK may produce synergistic effect.

\section{Conclusion}

In summary, hirsutanol A is a ROS generating agent which exerts anticancer effect via up-regulation of ROS level and activation of mitochondria/cytochrome $c$ signaling pathway. Moreover, hirsutanol A could activate JNK signaling pathway. Activation of JNK signaling pathway did not mediate apoptosis; however, it could regulate ROS level in a negative feedback fashion which protects cells against oxidant stress induced cell death. Our results revealed that hirsutanol A may be a promising lead compound in future anticancer treatments.

\section{Competing interests}

The authors declare that they have no competing interests.

\section{Authors' contributions}

FY and WC carried out the molecular genetic studies, immunoassays and drafted the manuscript. $\mathrm{HZ}$ carried out the immunoassays. RD, JT, KW and $\mathrm{DL}$ participated in the design of the study and performed the statistical analysis. FY, GF conducted the in vivo study. WL, $\mathrm{HL}$ and $\mathrm{XZ}$ conceived of the study, and participated in its design and coordination and helped to draft the manuscript. All authors read and approved the final manuscript.

\section{Acknowledgements}

This work was supported by Major science and technology project of the National Basic Research Program (973 Program) of China (2012CB967004); National Natural Science Foundation of China [81001446,81272199]; Natural Science Foundation of Guangdong in China (S2012010008761, S2011020002759); Major science and technology project of Guangzhou (2010U1-E00531-5, 2011Y1-00036).

\section{Author details}

${ }^{1}$ State Key Laboratory of Oncology in South China, Cancer Center, Sun YatSen University, 651 Dongfeng Road East, Guangzhou 510060, China. ${ }^{2}$ School of Chemistry and Chemical Engineering, Sun Yat-Sen University, Guangzhou 510275, China. ${ }^{3}$ Department of Molecular Pathology, The University of Texas MD Anderson Cancer Center, Houston, TX 77030, USA. ${ }^{4}$ School of Pharmaceutical Sciences, Sun Yat-Sen University, Guangzhou 510006, China.

Received: 9 August 2012 Accepted: 21 January 2013

Published: 8 February 2013

\section{References}

1. Fang J, Seki T, Maeda H: Therapeutic strategies by modulating oxygen stress in cancer and inflammation. Adv Drug Deliv Rev 2009, 61(4):290-302.

2. Lu FX: Reactive oxygen species in cancer, too much or too little? Medical Hypotheses 2007, 69(6):1293-1298.

3. Schumacker PT: Reactive oxygen species in cancer cells: Live by the sword, die by the sword. Cancer Cell 2006, 10(3):175-176.

4. Pan JS, Hong MZ, Ren JL: Reactive oxygen species: A double -edged sword in oncogenesis. World J Gastroenterol 2009, 15(14):1702-1707.

5. Rachootham D, Alexandre J, Huang P: Targeting cancer cells by ROSmediated mechanisms: a radical therapeutic approach? Nat Rev Drug Discovery 2009, 8(7):579-591.

6. Trachootham $D$, Zhou $Y$, Zhang $H$, et al: Selective killing of oncogenically transformed cells through a ROS mediated mechanism by $\beta$-phenylethyl isothiocyanate. Cancer Cell 2006, 10(3):241-252.

7. Zhang H, Trachootham D, Lu W, et al: Effective killing of Gleevec- resistant CML cells with T3151 mutation by a natural compound PEITC through redox-mediated mechanism. Leukemia 2008, 22(6):1191-1199.

8. Danial NN, Korsmeyer SJ: Cell death: critical control points. Cell 2004, 116(2):205-219.

9. Hang $P$, Oliff A: Signaling pathways in apoptosis as potential targets for cancer therapy. Trends Cell Biol 2001, 11(8):343-348.

10. Mark GH, Catherine LD: Regulation of apoptosis: uncovering the binding determinants. Curr Opin Struct Biol 2005, 15(6):690-699.

11. Benhar M, Engelberg D, Levitzki A: ROS stress-activated kinases and stress signaling in cancer. EMBO 2002, 3(5):420-425.

12. Ricci JE, Munoz-Pinedo C, Fitzgerald P, et al: Disruption of Mitochondrial Function during Apoptosis is Mediated by Caspase Cleavage of the p75 Subunit of Complex I of the Electron Transport Chain. Cell 2004, 117(6):773-786.

13. Lee $\mathrm{DH}$, Park T, Kim HW: Induction of apoptosis by diaturbing mitochondrial-membrane potential and cleaving PARP in Jurkat T cells through treatment with acetoxyscripenol mycotoxins. Biol Pharm Bull 2006, 29(4):648-654.

14. Kuwabara M, Asanuma T, Inanami O: Regulation of cell survival and death signals induced by oxidative stress. J Clin Biochem Nutr 2008, 43(2):51-57.

15. Li DD, Wang LL, Deng $\mathrm{R}$, et al: The pivotal role of c-Jun $\mathrm{NH} 2$-terminal kinase-mediated Beclin1 expression during anticancer agents-induced autophagy in cancer cells. Oncogene 2009, 28(6):886-898.

16. Kops GJ, Dansen TB, Polderman PE, et al: Fokhead transcription factor FOXO3a protects quiescent cells from oxidative stress. Nature 2002, 419(6904):316-321.

17. Wang GYS, Abrell LM, Avelar A, et al: New hirsutane-basesquiterpenes from salt water cultures of a marine sponge-derived fungus and the terrestrial fungus Coriolus consors. Tetrahedron 1998, 54(26):7335-7342.

18. Yang F, Wu KW, Li DD, et al: A novel sesquiterpene hirsutanol A induces autophagical cell death in human hepatocellular carcinoma cells by increasing reactive oxygen species. Chin J Caner 2010, 29(7):665-660.

19. Li HJ, Lan WJ, Lam CK, et al: Hirsutane sesquiterpenoids from marinederived fungus Chondrostereum sp. Chem Biodivers 2011, 8(2):317-324.

20. Chen LM, Wu XP, Ruan JW, et al: Screening novel, potent multidrugresistant modulators from imidazole derivatives. Oncol Res 2004 
14(7-8):355-62.19

21. Sewell JM, Mayer I, Langdon SP, et al: The mechanism of action of Kahalalide F: variable cell permeability in human hepatoma cell lines. Eur J Cancer 2005, 41(11):1637-1644.

22. Zhang JY, Wu HY, Xia XK, et al: Anthracenedione derivative 1403P-3 induces apoptosis in KB and KBv200 cells via reactive oxygen speciesindependent mitochondrial pathway and death receptor pathway. Cancer Biol Ther 2007, 6(9):1413-1421.

23. Zhou JM, Zhu XF, Lu YJ, et al: Senescence and telomere shortening induced by novel potent G-quadruplex interactive agents, quindoline derivatives, in human cancer cell lines. Oncogene 2006, 25(4):503-511.

24. Liu JN, Deng R, Guo JF, et al: Inhibition of myc promoter and telomerase activity and induction of delayed apoptosis by SYUIQ-5, a novel Gquadruplex interactive agent in leukemia cells. Leukemia 2007, 21(6):1300-1302.

25. Deng R, Li W, Guan Z, et al: Acetylcholinesterase expression mediated by c-Jun-NH2-terminal kinase pathway during anticancer drug-induced apoptosis. Oncogene 2006, 25(53):7070-7077.

26. Kristian T: Isolation of mitochondria from the CNS. Curr Protoc Neurosci 2010, 7(7):22.

27. Deng R, Tang J, Xia LP, et al: Excisanin A, a diterpenoid compound purified from Isodon MacrocalyxinD, induces tumor cells apoptosis and suppresses tumor growth through inhibition of PKB/AKT kinase activity and blockade of its signal pathway. Mol Cancer Ther 2009, 8(4):873-882.

28. Li DD, Wu XQ, Tang J, Wei XY, Zhu XF, et al: ON-III inhibits erbB-2 tyrosine kinase receptor signal pathway and triggers apoptosis through induction of Bim in breast cancer cells. Cancer Biol Ther 2009, 8(8):739-743.

29. Darzynkiewicz Z, Juan G, Li X, et al: Cytometry in cell necrobiology: analysis of apoptosis and accidental cell death (necrosis). Cytometry 1997, 27(1):1-20.

30. Oyama Y, Hayashi A, Ueha T, et al: Characterization of 21,7/dichlorofluorescin fluorescence in dissociated mammalian brain neurons: estimation on intracellular content of hydrogen peroxide. Brain Res 1994, 635(1-2):113-117.

31. Bindokas VP, Jordan J, Lee CC, et al: Superoxide production in rat hippocampal neurons: selective imaging with hydroethidine. J Neurosci 1996, 16(4):1324-1336.

32. Al-Gubory KH, Fowler PA, Garrel C: The roles of cellular reactive oxygen species, oxidative stress and antioxidants in pregnancy outcomes. Int J Biochem Cell Biol 2010, 42(10):1634-1650.

33. Chen $F H$, Zhang $L B$, Qiang $L$, et al: Reactive oxygen species-mitochondria pathway involved in LYG-202-induced apoptosis in human hepatocellular carcinoma HepG2 cells. Cancer Lett 2010, 296(1):96-105.

34. Bennett DT, Sasaki BW, Murray EC, et al: SP600125, an anthrapyrazole inhibitor of jun N-terminal kinase. Proc Natl Acad Sci USA 2001, 98(24):13681-13686.

35. Huang $P$, Feng $L$, Elizabeth $A$, et al: Superoxide dismutase as a target for the selective killing of cancer cells. Nature 2000, 407(6802):390-395.

36. Alexandre J, Hu Y, Lu WQ, et al: Novel Action of Paclitaxel against Cancer Cells; Bystander Effect Mediated by Reactive Oxygen Species. Cancer Res 2007, 67(8):3512-3517.

37. Marchi S, Giorgi C, Suski JM, et al: Mitochondria-ros crosstalk in the contro of cell death and aging. J Signal Transduct 2012, 2012:329635. doi:10.1155/ 2012/329635.

38. Han YH, Park WH: The effects of $\mathrm{N}$-acetyl cysteine, buthionine sulfoximine, diethyldithiocarbamate or 3-amino-1,2,4-triazole on antimycin A-treated Calu-6 lung cells in relation to cell growth, reactive oxygen species and glutathione. Oncol Rep 2009, 22(2):385-391.

39. Pelicano H, Carney D, Huang P: ROS stress in cancer cells and therapeutic implication. Drug Resist Updat 2004, 7(2):97-110

40. Valko M, Rhodes CJ, Moncol J, et al: Free radicals, metals and antioxidants in oxidative stress-induced cancer. Chem Biol Interact 2006, 160(1):1-40.

\section{doi:10.1186/1479-5876-11-32}

Cite this article as: Yang et al:: Hirsutanol A, a novel sesquiterpene compound from fungus Chondrostereum sp., induces apoptosis and inhibits tumor growth through mitochondrial-independent ROS production: Hirsutanol A inhibits tumor growth through ROS production. Journal of Translational Medicine 2013 11:32.

\section{Submit your next manuscript to BioMed Central and take full advantage of:}

- Convenient online submission

- Thorough peer review

- No space constraints or color figure charges

- Immediate publication on acceptance

- Inclusion in PubMed, CAS, Scopus and Google Scholar

- Research which is freely available for redistribution 